\title{
Analysis of the Brand Cultural Shaping Mode of Modern Enterprises
}

\author{
Shiyingzi Huang \\ School of Management \\ Wuhan University of Technology \\ Wuhan, China
}

\begin{abstract}
Based on the four dimensions of brand culture, this paper uses case analysis and cross-case research methods to explore outstanding enterprises in the new era of local business environment by selecting three local Chinese companies, Huawei, Xiaomi and Haidilao as research cases. The understanding of brand culture provides an effective reference for Chinese companies to promote their development by focusing on brand culture. Three effective models of brand culture shaping are finally obtained in this study. The conclusions have important theoretical and practical significance for exploring the brand culture shaping mode of outstanding enterprises in the new era.
\end{abstract}

Keywords—shaping brand culture; shaping mode;brand culture internalizes; brand culture outreach

\section{INTRODUCTION}

From the perspective of the development process of enterprise competition, in general, the enterprise's competition process has gone through four stages. In the initial period of backward production and underdeveloped productivity, competition among enterprises in the same industry is a blue ocean, and the development orientation of enterprises is mainly based on production. With the further improvement of the productivity level, the competition of enterprises has become fierce, and the development mode of the enterprise has evolved into a sales-oriented orientation, and the focus is still on the inside. Since the modern times, the competition of enterprises in the same industry has gradually become the trend of the Red Sea. The brand has begun to follow the marketing orientation and position the market demand to stand out from the competition. Various enterprises use various marketing methods and marketing methods, but the marketing modes of each enterprise tend to be homogenized. . Today's enterprises have begun to further explore the new orientation in the development of competition: brand-oriented, look back to find their own differences, and accumulate the differences and highlights of the brand. The most lasting meaning of a brand is their value, culture and personality, which is the basis for their brand. (Philippe Kotler. 2001) Among them, companies form tangible and intangible brand assets by shaping brand culture.

Looking at the existing literature, a lot of research at home and abroad mainly focuses on the study of brand culture and related dimensions and influencing factors. It does not explore the heterogeneity of the internal mechanisms and modes of different types of corporate brand culture construction, ignoring the brand's location. The impact of the environment and the brand's own situation on the branding mode of the brand culture adopted.
This study believes that due to the differences in the industry environment and the status of their own brands, there are differences in the shaping patterns of local corporate brand culture. This paper mainly explores the model of brand culture building through the four dimensions of corporate culture, products and services, brand personality concept and reputation, and brand ownership (zhang hongxia.2009), thus providing new reference ideas for enterprises to build brand culture mode. Marketing methods, consumer values, word of mouth, and social trends will have an impact on the process of brand culture. Brand ownership means that consumers and brands have emotional resonance, which is the ultimate goal of brand culture. (Zhang Hongxia. 2009). When the consumer's self-concept is consistent with the values conveyed by the brand culture, consumers will emotionally resonate with the brand (Sirgy 1982).

\section{SELECTION OF CASE COMPANIES}

In this study, Huawei, Xiaomi and Haidilao were selected as the analysis objects. The case selection was mainly due to the following considerations: (1) Adaptability. The case enterprises have made a series of effective attempts in corporate culture, product service, brand concept and reputation, brand ownership, etc., and achieved relatively obvious results, which is very suitable for this research. (2) Industry typicality. The industries in which the case enterprises are located are characterized by large scale, high industry value, and rapid changes in the industry. Moreover, the case enterprises have certain brand awareness and brand influence in the corresponding industries, which are very typical in the industry and suitable for the research. (3) Can be promoted. Due to the difference between the market environment and the status of the brand itself, the case enterprises have their own focuses in the four dimensions involved in the research, which form the difference of the brand culture shaping mode. These differences are conducive to the replication and expansion of the research conclusions. The research conclusions are generalized and referential.

\section{IN-CASE ANALYSIS}

\section{A. Analysis of the case of Huawei}

Huawei ranked first in the "2016 China Private Enterprises Top 500" list in 2016. The founder Ren Zhengfei himself is a military person. He believes that wolves are examples of corporate learning and effectively shape and spread wolf culture from the top down. On the basis of the formation of a distinctive and iconic wolf culture, through interviews and media communication, Huawei succeeded in making wolf 
culture a part of the corporate logo. In terms of product services, Huawei is committed to research and patent research. In recent years, Huawei has focused on $5 G \mathrm{R} \& \mathrm{D}$ and has an absolute leading edge in $5 \mathrm{G}$ solutions. It is the attitude of focusing on technology research and development that has made Huawei have a very good reputation in terms of products.
At the same time, Huawei is very nationalistic. It is this kind of national entrepreneurial spirit that has aroused the cultural identity and strong resonance of consumers. In addition, Huawei has further enhanced consumer identity by selecting spokespersons that are consistent with the cultural values of the company.

TABLE I ANALYSIS OF THE CASE OF HUAWEI ENTERPRISE

\begin{tabular}{|c|c|c|c|}
\hline Dimensional factor & behavioral measure & typical evidence cited & effect \\
\hline Corporate Culture & $\begin{array}{l}\text { Shaping "Wolf Culture" and } \\
\text { "Cushion Culture" }\end{array}$ & $\begin{array}{l}\text { In public interviews, Huawei's leader repeatedly } \\
\text { talked about and publicized the "wolf culture" } \\
\text { and "mat culture" that Huawei advocated }\end{array}$ & $\begin{array}{l}\text { effectively promoted Huawei's corporate } \\
\text { culture. Achieve deep roots }\end{array}$ \\
\hline Products and services & $\begin{array}{l}\text { Focus on scientific research, } \\
\text { quality first }\end{array}$ & $\begin{array}{l}\text { Focus on } 5 \mathrm{~g} \text { research and development; the } \\
\text { number of } R \& D \text { patents is leading the world }\end{array}$ & $\begin{array}{l}\text { Keep the high quality of the products and be } \\
\text { able to be well-received in terms of products }\end{array}$ \\
\hline $\begin{array}{l}\text { Brand personality, } \\
\text { concept and reputation } \\
\text { consumption Resonate }\end{array}$ & $\begin{array}{l}\text { Spokesperson effect, } \\
\text { promoting the concept of } \\
\text { Huawei's struggle and } \\
\text { national brand }\end{array}$ & $\begin{array}{l}\text { Choosing the young idol Yi Qian Qian as a } \\
\text { celebrity spokesperson, further shaping the } \\
\text { brand concept of endeavor and endorsement for } \\
\text { the nation }\end{array}$ & $\begin{array}{l}\text { Further shaping a good image in the hearts of } \\
\text { consumers, causing }\end{array}$ \\
\hline Brand affiliation" & $\begin{array}{l}\text { to promote the national spirit } \\
\text { and guide consumers to } \\
\text { resonate }\end{array}$ & $\begin{array}{l}\text { After the Meng Zhouzhou incident, she said: } \\
\text { "We are proud of Huawei and proud of the } \\
\text { motherland." }\end{array}$ & $\begin{array}{l}\text { cause strong national resonance and identity of } \\
\text { our compatriots }\end{array}$ \\
\hline
\end{tabular}

\section{B. Analysis of the case of Xiaomi}

Xiaomi's corporate vision is "to make everyone enjoy the fun of technology". In order to achieve such a goal, Xiaomi Company has made products with geek spirit, and has carried out innovative subversion in the fields of Internet smart TV, home smart router and smart home products. Xiaomi is committed to the continuous extension and innovation of the product chain. At present, Xiaomi's products have covered all aspects of life. At the same time, Xiaomi adheres to the concept of open cooperation, adhering to the open and non-exclusive cooperation strategy, and working with industry partners to promote the construction of intelligent ecological chain. Let everyone enjoy the technology is also the philosophy of Xiaomi. The high cost performance and the price of the people also enable consumers to truly realize the ability to purchase and have the willingness to use. In order to enable consumers to feel the feeling of home in Xiaomi's products, Xiaomi's brand, Mijia, contains various home sports smart products such as Xiaomi mobile power, Xiaomi bracelet, Xiaomi air purifier, etc.

TABLE II ANALYSIS OF THE CASE OF XIAOMI ENTERPRISE

\begin{tabular}{|l|l|l|l|}
\hline Dimensional factor & behavioral measure & typical evidence cited & effect \\
\hline Corporate Culture & $\begin{array}{l}\text { "Everyone can enjoy the } \\
\text { fun of technology" }\end{array}$ & $\begin{array}{l}\text { Founder Lei Jun stressed at the new product } \\
\text { launch: "Millet guarantees less than 5\% profit on } \\
\text { hardware, allowing consumers to enjoy technology } \\
\text { at the best price" }\end{array}$ & $\begin{array}{l}\text { Formed a distinctive brand style, cost-effective } \\
\text { reputation }\end{array}$ \\
\hline Products and services & $\begin{array}{l}\text { Carrying out product value } \\
\text { chain extension and } \\
\text { innovation }\end{array}$ & $\begin{array}{l}\text { Millet products extend to all aspects of life: Xiaomi } \\
\text { MIX, Mijia sweeping robot, Mijia smart rice } \\
\text { cooker, etc }\end{array}$ & $\begin{array}{l}\text { The extension of the product chain makes the } \\
\text { brand value bigger }\end{array}$ \\
\hline $\begin{array}{l}\text { Brand personality, } \\
\text { concept and reputation } \\
\text { consumption Resonate }\end{array}$ & $\begin{array}{l}\text { Adhere to the concept of } \\
\text { open cooperation }\end{array}$ & $\begin{array}{l}\text { Working with industry partners to build a smart } \\
\text { ecosystem }\end{array}$ & $\begin{array}{l}\text { Win the trust of partners and consumers and } \\
\text { further shape the brand culture. }\end{array}$ \\
\hline Brand affiliation" & $\begin{array}{l}\text { Launched the "Mijia" } \\
\text { brand }\end{array}$ & $\begin{array}{l}\text { "Mijia" includes products such as Xiaomi Mobile } \\
\text { Power, Huami Technology's Xiaomi Bracelet, etc }\end{array}$ & Enhance consumer sentiment \\
\hline
\end{tabular}

\section{Analysis of the case of Haidilao}

Haidilao has adhered to the service concept of "service first, customer first" for many years, and has impressed countless consumers with its meticulous service attitude and exquisite products. Adhering to the concept of thinking for customers, Haidilao has set up more than a dozen hot pot types. When you eat hot pot, you can get free fruits and drinks. All dishes can be called half serving. And because diners often have to line up, and the restaurant provides free nails, shoes, and hands guards for customers waiting. In order to provide customers with thoughtful service, the attitude of the staff is very good, they pay attention to the needs of customers, and even have a special service in the bathroom. When the customer is pregnant, they will receive special gifts and treatment. In order to prevent consumers from leaving the smell of smoke on the clothes after eating the hot pot, Haidilao invented the hot pot without leaving the oil smoke. As such, Haidilao has a very good reputation among consumers. 
TABLE III ANALYSIS OF THE CASE OF HAIDILAO ENTERPRISE

\begin{tabular}{|l|l|l|l|}
\hline Dimensional factor & behavioral measure & typical evidence cited & effect \\
\hline Corporate Culture & $\begin{array}{l}\text { "Service first, customer } \\
\text { first" }\end{array}$ & $\begin{array}{l}\text { Invented the hot pot without leaving a cigarette } \\
\text { and applied for a patent }\end{array}$ & $\begin{array}{l}\text { From the inside to the outside, it has shaped } \\
\text { and spread the "customer first" corporate } \\
\text { culture }\end{array}$ \\
\hline Products and services & $\begin{array}{l}\text { A wide range of products, } \\
\text { thoughtful service }\end{array}$ & $\begin{array}{l}\text { Free nail art, beauty shoes, hand guards and } \\
\text { other services for customers waiting }\end{array}$ & $\begin{array}{l}\text { Give consumers a good sense of consumer } \\
\text { experience }\end{array}$ \\
\hline $\begin{array}{l}\text { Brand personality, } \\
\text { concept and } \\
\text { reputation } \\
\text { consumption } \\
\text { Resonate }\end{array}$ & Humanized brand concept & $\begin{array}{l}\text { Employees are enthusiastic and considerate, and } \\
\text { consumers with special needs such as pregnant } \\
\text { women are often taken care of }\end{array}$ & Consumer word-of-mouth communication \\
\hline $\begin{array}{l}\text { Brand affiliation" } \\
\text { and feel the }\end{array}$ & $\begin{array}{l}\text { Let customers not set a snoring time and leave a doll for the } \\
\text { feeling of home. }\end{array}$ & $\begin{array}{l}\text { Enhance the brand identity of consumers and } \\
\text { make consumers feel at home }\end{array}$ \\
\hline
\end{tabular}

\section{CROSS-CASE ANALYSIS}

Through the analysis of the internal and external environment and the brand culture shaping methods of the above cases, we have obtained the following three brand culture shaping modes.

\section{A. Oriented mode}

With Huawei as the representative, companies adopting such modes often have brand characteristics with strong core values and weak brand substitutability. Such brands usually focus on the control of core products and core technologies, and have relatively strong financial strength. In terms of brand culture, such enterprises focus on the dissemination of the core slogans or concepts of the enterprise, and pay attention to the guarantee of product quality, and positively influence the brand resonance by improving product quality (Ma Chunlin, 2011; Xiao Wei and Li Jianjun, 2008). On the other hand, it will use the spokesperson effect and other methods to shape and disseminate a highly cohesive brand culture. By constructing a high degree of consistency in brand culture and guiding consumers' emotional belonging, they can obtain emotional resonance of consumers and enhance customer satisfaction (Jamal and Goodc, 2001; Jamaland AL-Marri, 2007; Ibrahim and Najar, 2008; Hosany and Marin, 2012; Dong Dahai, 2009).

\section{B. Extended mode}

Represented by xiaomi, enterprises adopting this kind of mode often have general core value and brand substitutability.
In terms of brand culture building, such enterprises tend to pay more attention to brand culture outreach while building and disseminating internal culture. Them through vertical and horizontal extension of product value chain, industry chain integration, the way such as strengthening core value of brand core value, and through the theory of value migration (Vukasovi, 2012) upgrade the brand value of migration and dissemination, and through the outstanding cost performance to make up for the defect of brand alternative ways, through the above ways to achieve the goal of the overall shape and strengthen brand culture.

\section{Experiential mode}

Represented by haidilao, enterprises adopting this mode often have the characteristics of weak core value and strong brand substitutability, among which the service enterprises are the majority. In terms of brand culture building, such brands often pay attention to the cultivation of internal quality and corporate culture of employees, especially front-line employees, so as to achieve the internalization of brand culture They tend to develop a school of one's own style of service as part of their products, through meticulous service to customers provide the best service experience, and focus on service in the process of individuation, human nature and the sense of "temperature" to win the consumer word of mouth, to realize the process of brand culture outreach, to enhance the brand value, strengthen brand characteristics, finally achieve the goal of shaping quality brand culture.

TABLE IV COMPARISON OF BRAND CULTURE SHAPING MODE

\begin{tabular}{|c|c|c|c|}
\hline \multirow{2}{*}{ brand attributes } & \multicolumn{2}{|l|}{ behavior of shaping brand culture } & \multirow[t]{2}{*}{ shaping mode } \\
\hline & brand culture internalizes & brand culture outreach & \\
\hline $\begin{array}{l}\text { The core value is strong, brand } \\
\text { substitutability is weak }\end{array}$ & $\begin{array}{l}\text { "Wolf culture" mold, enterprise } \\
\text { story mold; Founder charisma; } \\
\text { Developing core technology }\end{array}$ & $\begin{array}{l}\text { strengthening product quality, spokesmen } \\
\text { promotion effect, brand spirit advocacy -- } \\
\text { building self-consistency }\end{array}$ & $\begin{array}{l}\text { Oriented mode } \\
\text { (huawei) }\end{array}$ \\
\hline $\begin{array}{l}\text { Core value is general, brand } \\
\text { substitutability is general }\end{array}$ & $\begin{array}{lll}\text { Corporate } & \text { vision } & \text { and } \\
\text { implementation } & & \end{array}$ & $\begin{array}{l}\text { Strengthening the internal quality of the brand, } \\
\text { highlighting the cost performance, extending } \\
\text { the product value chain -- the extension of } \\
\text { brand value }\end{array}$ & $\begin{array}{l}\text { Extended mode } \\
\text { (xiaomi) }\end{array}$ \\
\hline $\begin{array}{l}\text { The core value is week, brand } \\
\text { substitutability is strong }\end{array}$ & $\begin{array}{l}\text { the internal enterprise culture of } \\
\text { employees is cultivated }\end{array}$ & $\begin{array}{llr}\text { Enhance } & \text { consumer } & \text { experience; } \\
\text { Word-of-mouth communication; } & \text { Personalized } \\
\text { service } & \end{array}$ & $\begin{array}{l}\text { Experiential mode } \\
\text { (haidilao) }\end{array}$ \\
\hline
\end{tabular}




\section{DISCUSSION}

Through the above intra-case analysis and cross-case analysis of the three case companies, it is not difficult to find that the above case companies in the process of brand culture building and strengthening, some means and ways of overlap. Due to the differences in the operating environment of enterprises and the characteristics of brands, there are also differences in the shaping modes of brand culture, and finally three different types of shaping modes are formed.

\section{A. Theoretical contribution}

(1) Starting from the four dimensions of brand culture, this study conducted targeted research on the internal ways and mechanisms of brand culture building of the case enterprise.

(2) On the basis of considering the differences of the environment and brand characteristics of the case enterprise, this study summarizes and refines three different models of cultural shaping.

\section{B. Actual contribution}

(1) Based on the actual situation, this study proposes different models of cultural shaping through the study of the ways of brand culture shaping of modern excellent enterprises, and provides models and schemes for other enterprises to use for reference, which is of strong practical reference.

(2) The effective means for excellent enterprises to build brand culture summarized in this study, such as the spokesman effect and brand value chain extension, can provide new ideas for other enterprises to build brand culture.

\section{CONCLUSION}

The study concluded that: (1) In recent years, many companies have increasingly recognized the importance of corporate culture in the process of enterprise development. (2) The company mainly achieves the effect of shaping the brand culture through the internal and external and external exhibition of brand culture. (3) Due to the difference between the market environment of the selected case enterprises and their own brand status, three different brand culture activation modes of orientation, extension and experience were formed. The conclusions of this study have important theoretical and practical significance for exploring the brand culture shaping mode of outstanding enterprises in the new era.

\section{REFERENCES}

[1] Zhang Hongxia. Exploratory research on brand connotation and influencing factors. Nankai management review.2009(10) : 99-101

[2] Philip kotler. Marketing management. Beijing: tsinghua university press. 2001

[3] Dong Dahai. Research progress of western consumer attachment theory [J]. Management review, 2009, 21(1):77-86.

[4] Ma Chunlin. Research on regional brand equity of agricultural products from the perspective of consumers [D]. Huazhong agricultural university, 2011.

[5] Xiao long, Li Jianjun. Influence of sponsorship propagation on sponsorship brand -- an empirical study based on Chinese corporate sponsorship $[\mathrm{J}]$. Contemporary finance and economics, 2008(10):100-105.A,

[6] Jamal Al - Marri m. Exploring the effect of self - image congruence and brand preference on satisfaction: the role of expertise [J]. Journal of Marketing Management, 2007, 23 (7-8) : 613-629.

[7] VukasovicT., 2012, "SearchingforCompetitiveAdvan-tage have The Brand Extension Process", Journal of Product \& Brand Management, 21 (7), pp. 492-498 